\title{
Global Response in Viscera
}

National Cancer Institute

\section{Source}

National Cancer Institute. Global Response in Viscera. NCI Thesaurus. Code C159963.

Criteria for the response to treatment in viscera, as a component of global response. 